\title{
199STE BESTUURSVERGADERING,
}

GEHOUDEN 19 APRIL 1879.

Tegenwoordig de heeren: van der Gon Netscher, Corns. de Groot, Robidé van der Aa, Kern, Meinsma, Niemann, Lammers van Toorenburg, Humme (Penningmeester) en Wijnmalen (Secretaris).

Afwezig de heeren Mirandolle, van Rappard en van Goltstein. De beide laatstgenoemden met kennisgeving.

Wegens de afwezigheid van den heer van Rappard, Voorzitter, eu van Goltstein, Onder-Voorzitter, neemt de heer van der Gon Netscher, als oudste in jaren, de voorzittersplaats in.

De notulen van het verhandelde in de vorige vergadering worden gelezen en goedgekeurd.

Door den Secretaris-Bibliothecaris wordt voorlezing gedaan van de titels der sedert de vorige bijeenkomst ten geschenke ontvangen boekwerken. Meer bepaald wordt daarbij de aandacht gevestigd op een van het lid van Musschenbroek ontvangen handschrift, waaromtrent voorgesteld wordt den gever, onder dankbetuiging voor het geschenk, beleefd uittenoodigen der vergadering met eenige beschrijving er van te willen verplichten. Dienovereenkomstig wordt besloten.

De tijdelijke Voorzitter deelt vervolgens de ontvangst mede van:

I. eene missive van den Minister van Koloniën, dd. 15 Maart ll., lett. A, no 65 , ten geleide van een exemplaar van den jaargang 1866 van het Staatsblad van Nederl. Indië.

II. twee missives van den Minister van Marine, dd. 15 Maart jl. lett. H., no. 56 en 7 April jl. lett. H., no. 54, waarbij voor de Bibliotheek van het Instituut wordt aangeboden een exemplaar der zeekaarten, die vanwege het Departement van Koloniën zị̄n uitgegeven; onder welke bezending niet begrepen zijn :

$\downarrow^{0}$. de kaarten, in eigendom toebehoorende aan, en verkocht 
wordende door de firma de Wed. G. Hulst van Keulen, te Amsterdam;

20. de kaarten vanwege het Departement van Koloniën in vroegeren tijd uitgegeven, die, als verouderd en door nieuwere uitgaven vervangen, thans niet meer in voorraad voorhanden zijn ;

30. de kaart "straat Madura ", waarvan tijdelịk geen exemplaren beschikbaar zijn.

III. eene missive van den Minister van Marine, dd. 9 April 1879 , lett. A. no. 51, ten geleide van een exemplaar van het "Jaarboek der Koninklijke Nederlandsche Zeemagt 1877-78" door de zorg van het Departement uitgegeven.

De in de missives sub I-III vermelde boeken en kaarten zullen in de boekerij worden geplaatst, terwijl voor de toezending daarvan bereids de dank van het Instituut is betuigd.

IV. eene missive van den Minister van Buitenlandsche Zaken, dd. 31 Maart jl., Afd. A. S., no. 52, houdende mededeeling, ingevolge het verzoek van $\mathrm{Zr}$ Ms. Minister-Resident te Lissabon, Z. Exc. den heer A. Mazel, van eene lijst, bevattende de titels der gedrukte bescheiden, welke hem omtrent de koloniën van Portugal door tusschenkomst van den Portugeeschen Minister van Binnenlaudsche Zaken zijn geworden voor de bibliotheek van het Instituut, onder bijvoeging voorts dat genoemde Minister-Resident voornemens is die boekwerken bij de eerste gelegenheid in eene afzonderlijke kist rechtstreeks aan het Instituut te doen toekomen.

Wordt besloten, onder dankbetuiging aan den Minister van Buitenlandsche Zaken voor de gedane mededeeling, de toezending der beloofde werken af te wachten, alvorens Zr. Ms. Minister-Resident te Tissabon de erkentelijkheid van het Instituut te betuigen voor de welwillendheid waarmeê aan het verzoek van het Instituutsbestuur is voldaan.

V. eene missive van het Bestuur van het Indisch Genootschap, van 16 April jl., waarbij aan het Instituot worden teruggezonden de deelen XXXI, XXXII, afl. 4-6, XXXIII en XXXIV van het Tijdschrift der Kon. Natuurkundige Vereediging in Ned. Indië, welke vroeger door het Instituut aan het Indisch Genootschap, ter plaatsing in zijne bib'iotheek, waren afgestaan, 
Overeenkomstig het voorstel van den Secretaris-Bibliothecaris wordt de behandeling dezer missive aangehouden.

V! , eene missive van het bestuurslid, Corns. de Groot, van den 17 Maart 1879, ten geleide van een drietal werken voor de bibliotheek van het Instituut.

Plaatsing daarvan in de boekerij, terwijl, overeenkomstig het voorstel van den Secretaris-Bibliothecaris, door den tijjelijken Voorzitter aan het bestuurslid Corns. de Groot, ter vergadering tegenwoordig, de dank van het Instituut wordt betuigd voor zijne verrijking der bibliotheek.

VII. eene missive van het Bestuur van het Indisch Geuootschap van 16 April 1879, houdende mededeeling, dat gemeld Bestuur besloten heeft zich te vereenigen met het dezerzijds gedaan voorstel om de bibliotheken van het Instituut en het Genootschap te beginnen met 10 . Mei a. s., met uitzondering van Zon- en feestdagen, dagelijks toegankelijk te stellen, telkens van 12 tot 4 ure des namiddags.

Naar aanleiding dezer missive wordt besloten, te beginnen met genoemden datum, de bibliotheken der beide instellıngen gedurende de evenvermelde uren dagelijks open te stellen; de uitvoering van dit besluit op te dragen aan den SecretarisBibliothecaris; overeenkomstig zijn advies den leden van beide instellingen bij circulaire van het genomen besluit kennis te geven, en aan het aan den gevel geplaatste bordje de noodige verandering te brengen met betrekking tot de aanwijzing van de dagen en uren, waarop de bibliotheken zijn geopend.

Door den Secretaris-Bibliothecaris wordt der vergadering voor het arehief een overdruk aangeboden van het in de jongst verscuenen aflevering der Bijdragen opgenomen verslag van deu staat der bibliotheken van het Instituut en Indisch Genootschap van 1 Mei-31 Dec. 1878.

Bij monde van den tijdelijken Voorzitter wordt hem daarvoor de dank der vergadering betuigd.

De tijdelijke Voorzitter deelt mede dat nog zijn ontvangen:

I. eene missive van het Aardrijkskundig Genootschap van 11 April jl., houdende dankbetuiging voor de toezending van de laatst verschenen aflevering der Bijdragen.

Voor kennisgeving aangenomen bownloaded from Brill.come4/26/2023 10:49: 09AM 
II. eene missive van de Koninklijke Akademie van Wetenschappen te Amsterdam, van 22 Mart jl., $\mathrm{n}_{0}$. 55, houdende dankbetuiging voor de toezending van de laatst verschenen aflevering der Bijdragen, met verzoek om het in de verzameling ontbrekende IIe dl., stuk 2, van de $4_{\mathrm{e}}$ Reeks, zoo mogelijk, alsnog toe te zenden.

Voor kennisgeving aangenomen, terwijl den Secretaris wordt opgedragen aan het gedaan verzoek, zoo mogelijk, te voldoen.

III. een gedrukte missive van de Societé de Géographie de Lisbonne van den volgenden inhoud:

Lisbonne, le 17 Mars 1879.

\section{COMMUNICATION IMPORTANTE.}

La Société de Géographie de Lisbonne a la vive satisfaction de vous communiquer la suivante dépêche qui vient de lui être transmise par le gouvernement portugais:

"Pretoria... Aden 16,-10 heures matin.

Ministre des Colonies-Lisbonne.

Je baise les mains de Sa Majesté.

Je me trouve à 6 journées de l'Océan Indien, à la veille de terminer ma traversée de l'Afrique, depuis la côte onest. J'ai lutté contre la faim et la soif, les bêtes féroces, les sauvages, les inondations et la sécheresse; $j$ 'ai heureusement surmonté tous ces obstacles.-?-Travaux sauvés: vingt cartes géographiques, trois volumes de coordonnées importantes, études météorologiques, trois volunes de dessins, un volumineux journal. J'ai perdu beaucoup de monde. Étude complete du Haut Zambeze, soixante douze cataractes et rapides. Plan des cataractes. Indigènes féroces, guerres constantes. Le secret du Cubango. J'écris par la poste.

Serpa Pinto."

Cet explorateur était parti de Bihé en Mai 1878.

Le Président de la Société José Vincente Barboza du Bogage.

Le ler Secrétaire Général Luciano Cordeiro.

Le 2d Secrétaire Général Rodrigo Affonso Pequito.

Voor keunisgeving aangenomen, 
IV. eene gedrukte missive van de Section Fratçaise du Comité international d'étude pour l'exploration de l'Isthme Américain te Parijs, ten geleide van eenige exemplaren bevattende de vraagpunten ter behandeling op het Interuationaal Congres, dat te Parijs den 15en Mei a. s. zal bijeenkomen.

Voor kennisgeving aangenomen.

V. eene missive van de Société de géographie de Genève, van 20 Maart jl., houdende verzoek om een letterkundig verkeer te openen, inzonderheid door ruiling van wederzijdsche uitgaven.

Wordt besloten aan het Genootschap te berichten, dat in het gedaan verzoek niet kan worden getreden, daar de werkkring van het Instituut, dat zich tot de bevordering van de Indische taal-, land en volkenkunde bepaalt, een ander is dan die van het Genootschap, en derhalve een letterkundig verkeer tusschen beide instellingen geene vruchten zal afwerpen.

Door het Bestuurslid Robidé van der Aa wordt mondeling rapport uitgebracht over het door den heer Leupe aangeboden opstel over de "overname van Ternate van de Engelschen in $1803 "$; het sluit zich aan de reeds vroeger door genoemd correspondeerend lid in de Bijdragen geplaatste stukken over hetzelfde onderwerp.

Overeenkomstig zijn advies besluit de vergadering tot opneming van het opstel in de Bijdragen.

Door den Secretaris wordt voorlezing gedaan van een schrijven van Commissarissen uit Indië, gedagt. Batavia, 14 Febr. 1879, Ia. B. 25, waarbij zij

10. overmaken een wissel tot een bedrag van $f 1657.86$, sluitpost hunner rekening en verantwoording over 1878, welke tevens er bij wordt gevoegd met eene lijst van de ontvangen contributiën; van de achterstallige contributiën van leden in Indië; van de naar Nederland vertrokkenen, met opgaaf wat zij schuldig waren, benevens een opgaaf van de leden die bedankt hebben en overleden zijn.

20. zenden Commissarissen boekwerken, die bij vergissing aan hen geadresseerd zijn, vermoedelijk door verwarring van het Instituut met het Bataviaasch Genootschap; daaronder is een deeltje van de werken van de nieuw.opgerichte Straits Branch van de Royal Asiatic Society, welke ruiling verzoekt; om 
daaıan te voldoen hehben Commissarissen gezonden het $\mathrm{X}^{\mathrm{e}}$, $\mathrm{XIe}$ en $\mathrm{Ie}$ deel der nieuwe volgsreeks, mitsgaders het $1^{\mathrm{e}}$ stuk van het $\mathrm{Te}$ deel, uit eigen boekerij nog aangevuld het le stuk van het Ie deel, dat niet meer voorhanden was, en waarvan restitutie wordt verzocht.

30. eindelijk deelen Commissarissen mede, dat zij voorloopig blijven fungeeren, terwijl de heer Bergsma terugkomt op zijn verzoek om van de ledenlijst te worden afgevoerd.

Overeenkomstig het voorstel van den Secretaris wordt na eenige gedachtenwisseling besloten: de sub $1^{0}$ vermelde stukken in handen te stellen van den Penningmeester en den Secretaris te machtigen in overleg met dien titularis daaromtrent aan Commissarissen te schrijven, onder dankbetuiging tevens voor hunue bebartiging der belangen van het Instituut; voorts de ontrangst van de sub 20. bedoelde boekwerken te erkeunen en het nieuw opgerichte Genootschap te plaatsen op de lijst der Instellingen, waarmeê het Instituut in betrekking staat en aan Commissarissen restitutie te geven van de door heu aan genoemd Genootschap afgestane afleveringen der Bijdragen; en eindelijk van het sub $3^{0}$. vermeld besluit aanteekening te houden.

\section{Nog is ingekomen:}

I. eene missive van het lid J. A. Jeekel, te Leerdam, houdende mededeeling dat hij zijn ontslag neemt als lid van het Instituut.

II. eene missive van den heer A. J. Blijdenstein, te Enschedé, waarbij hij, onder dankbetuiging voor de eer hem bewezen, hericht de benoeming tot lid van het Instituut niet te kunnen aanvaarden.

De missives sub I en II worden voor kennisgeving aangenomen.

III. eene missive van den heer V. M. Baron d'Ablaing van Giessenburg, te 's Gravenhage, van 18 Maart jl., houdende mededeeling dat hij, hoewel erkentelijk voor de aanbieding van het lidmaatschap van het Instituut, echter tot deze instelling niet durft toetreden. Terwijl hij zeer veel belang heeft gesteld en nog stelt in den bloei en voorspoed van onze Oost-Indische bezittingen, hoofdzakelijk om de bezittingen zelve en hunne inwoners, heeft hem evenwel gedurende de laatste dertig jaren het bestieren van die bezittingen door en uit Nederland zeer veel leed gedaan, te meer daar het volgens zijne meening ge- 
schiedde niet overeenkomstig den inborst en aanleg van den Oosterling. Het zoude hem daarom vroeger hoogst aangenaam zijn geweest, indien hij, maar iets ook, had kunnen bijdragen tot eene verandering van zienswijze daaromtrent in Nederland, doch na reeds \pm 25 jaren Java te hebben verlaten en nu oud geworden, gevoelt hij, dat het zijne krachten zoude te boven gaan om nog in zijne richting voor of door het Instituut werkzaam te zijn.

Naar aanleiding dezer missive wordt, overeenkomstig het voorstel van den tijdelijken Voorzitter, besloteu den heer d'Ablaing van Giessenburg het leedwezen der vergadering te betuigen over zijne niet-toetreding tot het Instituut, terwijl zij, met betrekking tot de redenen, die hem tot zijn besluit hebben geleid, er prijs op stelt te verklaren dat het Instituut enkel het wetenschappelijk terrein als het zijne erkent waar het de bevordering bedoelt van de Indische taal-, land- en volkenkunde, terwijl het zich heeft gehouden en ook in het vervolg wil blijven houden buiten de politieke aangelegenheden van het moederland met betrekking tot zijne koloniën.

$\mathrm{Na}$ eenige gedachtenwisseling worden tot leden van het Instituut voorgedragen en door het Bestuur benoemd de hh.:

M. L. van Deventer, Consul-Generaal in Brazilië, thans met verlof;

Mr. P. W. $\Lambda$. Cort van der Linden, Commies-Griffier der Tweede Kaner van de Staten-Generaal;

J. C. A. van Asperen, Oud-Geograph. Ingenieur;

W. Beijerinck, Oud-Luitenant-Kolonel O. I. leger ;

Jhr. Mr. R. L. van den Bosch;

J. J, Blanckenhagen ;

Jhr. Th. van Cappellen, Oud-Resident;

mr. J. R. Couperus, Oud Raadsheer bij het Hof in N. I. ;

J. C. de Kock van Leeuwen, Oud-Resident in N. I.;

O. W. Swaving, Oud-Kesident van Manado;

E. Bosch, Assistent-Resident met verlof;

L. C. E. Kniphorst, Assistent-Resident, met verlof;

F. G. van Bloemen Waanders, Oud-Directeur binn. bestuur;

Jhr. mr. J. C. Reynst, Advocaat; - allen te 's Gravenhage. J. J. Naeff', laatst Controleur $1^{\mathrm{e}}$ klasse met verlof te Logehem. mr. A. Heemskerk, Rechter rechtbank te Zierikzee, bestuurder der Vereeniging Suriuame. 
W. F. C. Bijvanck, Leeraar in de geschiedenis van N. I., aan de Indische instelling te Leiden.

mr. Serrurier, Conservator van het Ethnographisch museum te Leiden.

R. W. Tadema, Adsistent-resident met verlof, te Zutfen.

dr. G. van Rijckevorsel, Natuurkundige, te Rotterdam.

mr. H. A. L. Hamelberg, Oud Consul-Generaal in de Transvaal, te Arnhem.

S. van Praag, oud-Lid der Kol. Staten te Paramaribo, te Amsterdam.

G. Birney, Particulier, te Velp.

G. P. J. van Koetsveld, Controleur le klasse, te Makassar.

L. W. Th. Schmidt, Onderwijzer aan de kweekschool voor inlandsche onderwijzers, te Makassar.

Van de benoeming van de beide laatstgenoemde in Indië gevestigde ambtenaren, die hunne toetreding tot het Instituut hebben verzocht, zal aan Commissarissen worden kennis gegeven.

Met het oog op het feit, dat van de West-Indische leden sedert de laatste jaren niets vernomen werd, terwijl ook voor de openbaarmaking van hunne studiën elders, en meer bepaald bij het Aardrijkskundig Genootschap de gelegenheid wordt aangeboden, wordt in overweging gegeven om den band met WestIndië langzamerhand los te maken. Terwijl dit denkbeeld ondersteund wordt, doch de verwezenlijking daarvan nog eenigen tijd wordt uitgesteld, vereenigt de vergadering zich met het voorstel van den Secretaris om inmiddels den Commissaris van het Instituut voor West-Indië met nadruk over onze betrekkingen tot die kolonie te onderhouden.

Aan den Penningmeester wordt, overeenkomstig zijn voorstel, machtiging verleend tot het illumineeren van het gebouw bij gelegenheid van den plechtigen intocht van HH. MM. den Koning en de Koningin in de residentie. Tevens wordt goedgekeurd, ten gebruike bij feestelijke gelegenheden, een vlag aan te schaffen.

Nog wordt de Penningmeester, overeenkomstig zijn advies, en gehoord de inlichtingen van zijn voorganger, het Bestuurslid de Groot, gemachtigd de rekening betreffende de calorifères, welke honger is dan anvankelijk geranmd was, te voldoen. 